\title{
THE UTILIZATION OF PET WASTE AS RAW MATERIAL FOR PRODUCING MONOFILAMENT YARN : THE EFFECT OF WINDING SPEED ON THE PHYSICAL AND MECHANICAL PROPERTIES OF THE YARN
}

\author{
Abdurrohman ${ }^{1}$, Valentinus Galih Vidia Putra ${ }^{1}$ and Akbar Hanif Dawam Abdullah ${ }^{2}$ \\ ${ }^{1}$ Department of Textile Engineering, Politeknik STTT Bandung \\ Jalan Jakarta No 31 Kota Bandung 40272 \\ ${ }^{2}$ Research Unit for Clean Technology, Indonesian Institute of Science (LIPI) \\ JalanCisitu-Sangkuriang, Bandung 40132 \\ E-mail: abdurrohman@stttekstil.ac.id
}

Received: 16 January 2020

Revised: 22 April 2020

Accepted: 30 April 2020

\begin{abstract}
THE UTILIZATION OF PET WASTE AS RAW MATERIAL FOR PRODUCING MONOFILAMENT YARN : THE EFFECT OF WINDING SPEED ON THE PHYSICAL AND MECHANICAL PROPERTIES OF THE YARN. Plastic waste production in Indonesia is quite high, reaching $15 \%$ to the total national waste production or 189-kilo tons/day with an average growth of $14.7 \%$ per year, the second biggest contributor after organic waste. This fact greatly affects human health and the environment since plastic is difficult to degrade, estimated to require 100 to 500 years for the plastic to decompose completely. Therefore, recycling becomes a popular solution to reduce waste or plastic waste by turning it into new products that have added value. Plastic materials, such as PET, have thermoplastic properties which become a special potential to use as recycled materials. The aim of this research was to study the ability of PET plastic waste as a raw material for making monofilament yarn by melt-spinning methods. PET plastic waste is melted at $250-260 \mathrm{oC}$, then is extruded using a prototype melt-spinning tool with a single spinneret hole which the diameter is $3 \mathrm{~mm}$ into a monofilament yarn using three variations of winding speed (a) $43.33 \mathrm{~m} / \mathrm{min}$, (b) $59.35 \mathrm{~m} / \mathrm{min}$ and (c) $72.72 \mathrm{~m} / \mathrm{min}$ The results showed that the yarn with the highest winding speed (variation C) produced yarn with the highest fineness, reaching (30.06 \pm 4.82$)$ denier, and the best tensile strength compared with the other, reaching $(47.7 \pm 14,97) \mathrm{MPa}$ with elongation of of $(10 \pm 9.65) \%$.
\end{abstract}

Keywords: plastic waste, PET, Melt Spinning, Monofilament yarn.

\begin{abstract}
ABSTRAK
PEMANFAATAN LIMBAH PET SEBAGAI BAHAN PEMBUATAN BENANG MONOFILAMEN : PENGARUH KECEPATAN PENGGULUNGAN TERHADAP SIFAT FISIK DAN MEKANIK BENANG. Produksi sampah plastik di Indonesia cukuplah tinggi,tercatat kontribusi sampah plastik terhadap total produksi sampah nasional mencapai $15 \%$ atau sebesar 189 kilo ton/hari dengan pertumbuhan rata-rata mencapai $14,7 \%$ per tahun dan menempatkan sampah plastik sebagai kontributor terbesar kedua setelah sampah organik. Penggunaan plastik dengan jumlah yang besar akan sangat berdampak terhadap kesehatan manusia dan lingkungan. Hal ini dikarena plastik mempunyai sifat sulit terdegradasi, diperkirakan membutuhkan 100 hingga 500 tahun agar plastik dapat terdekomposisi dengan sempurna. Oleh karena itu daur ulang menjadi solusi yang populer untuk mengurangi sampah atau limbah plastik dengan memanfaatkannya menjadi produk baru yang memiliki nilai tambah. Bahan plastik khususnya yang memiliki sifat termoplastik seperti PET memiliki daya tarik tersendiri untuk digunakan sebagai bahan daur ulang. Tujuan dari penelitian ini adalah untuk mengetahui kemampuan limbah plastik jenis PET sebagai bahan baku pembuatan benang monofilamen dengan metode pemintalan leleh. Limbah plastik jenis PET dilelehkan pada suhu $250-260^{\circ} \mathrm{C}$ yang kemudian diekstrusi menggunakan alat prototipe pemintalan leleh dengan lubang spineret tunggal berukuran $3 \mathrm{~mm}$ menjadi benang monofilamen dengan tiga variasi kecepatan penggulungan
\end{abstract}


The Utilization of PET Waste as Raw Material for Producing Monofilament Yarn: The Effect of Winding Speed on the Physical and Mechanical Properties of the Yarn (Abdurrohman)

(a) 43,33 $\mathrm{m} / \mathrm{mnt}$, (b) $59,35 \mathrm{~m} / \mathrm{mnt}$, dan (c) $72,72 \mathrm{~m} / \mathrm{mnt}$. Hasil penelitian menunjukan bahwa benang dengan kecepatan penggulungan paling tinggi dalam hal ini variasi $\mathrm{C}$ menghasilkan benang dengan kehalusan paling tinggi yaitu mencapai $(30,06 \pm 4,82)$ denier dan kekuatan tarik terbaik dibandingkan dengan variasi kecepatan penggulungan yang lain yakni mencapai $(47,71 \pm 4,97) \mathrm{MPa}$ dengan mulur $(10 \pm 9.65) \%$.

Kata kunci: limbah plastik, PET, Pemintalan leleh, Benang Monofilamen.

\section{INTRODUCTION}

Waste is a cultural problem which is one of the side products of human activities and its volume is directly proportional to the number of human populations in the area. This problem, if it is not handled properly, will damage the surrounding life. The largest source of waste is residential areas, comprising $75 \%$ organic waste and $25 \%$ inorganic waste [1]. Organic waste has been widely used for making compost, biogas, briquettes, etc. while inorganic waste is still rarely utilized due to its difficulty to degrade naturally. The largest type of inorganic waste that are often found in the environment is plastics [2].

Plastic is a very popular material to be used as material for making most household appliances, from beverage bottles, cups, plates, plastic bags, etc. [3]. Based on the type of product, there are 6 types of plastic namely PET (Polyethylene Terephthalate), HDPE (HighDensity Polyethylene), PVC (Polyvinyl Chloride), LDPE (Low-Density Polyethylene), PP (Polypropylene), and PS (Polystyrene) [4]. Generally, plastic waste has a composition of $46 \%$ Polyethylene (HDPE and LDPE), $16 \%$ Polypropylene (PP), 16\% Polystyrene (PS), 7\% Polyvinyl Chloride (PVC), 5\% Polyethylene Terephthalate (PET), 5\% Acrylonitrile-ButadieneStyrene (ABS) and other polymers.

PET is one of the most widely used man-made fibers since the mid-twentieth century [5]. PET with the trade name Dacron is made from terephthalic acid and ethylene glycol, while terylene is made from dimethyl terephthalate and ethylene glycol, the structure of Dacron and Terylene can be seen in Figure 1 below.

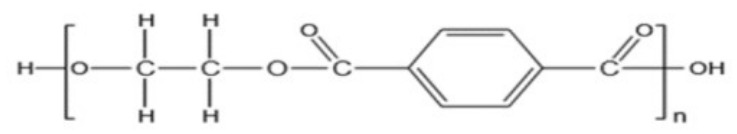

(a)

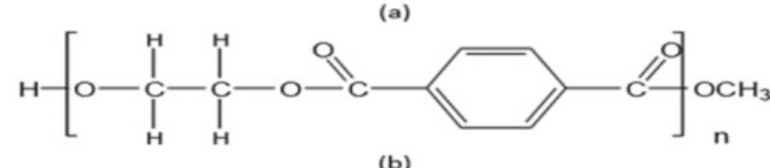

(b)

Figure 1. The properties of PET generally have been known as shown at Table 1

PET is a type of plastic that has thermoplastic properties [6]. PET would be soft if it heated, in revers it would harden if it cooled and this process can be done repeatedly. Thermoplastics are a type of plastic that can be recycled using heat $[7,8]$. The plastic recycling process that has thermoplastic properties (in this case PET) can be done in several ways : injection molding $[9,10]$, blow molding $[10,11]$, extrusion and melt-spinning[10]. Melt-spinning is one of the most widely used industrial processes to produce polymeric fibers [12]

Table 1. Properties of PET[5]

\begin{tabular}{ll}
\hline \multicolumn{1}{c}{ Property } & \multicolumn{1}{c}{ Value } \\
\hline $\begin{array}{l}\text { Mechanical Properties } \\
\text { Tensile Strength } \\
\text { Elongation } \\
\text { Young Modulus }\end{array}$ & $45-70 \mathrm{MPa}$ \\
\hline Chemical Properties & 2.8 to $3.5 \mathrm{GPa}$ \\
Weak Acid & \\
Strong cold acids & Resistant \\
Insecticides & Resistant \\
Oxidizing agents, alcohols, & Resistant \\
ketones, and soaps & Resistant \\
Moisture regain & \\
& $0,4 \%$ (Standar Condition) \\
& $0.6-0.8 \%$ (100\% Relative \\
& Humidity) \\
\hline
\end{tabular}

Aizenshtein (2015) explains the ways of utilizing used PET bottles as raw material to make less important products as staple fiber, fiber filler, etc. To get high-quality fibers or yarn, PET flakes must through the granulation process and special treatment first before it is extruded become POY, DTY, or staple yarn by melt-spinning process[13]. Noerati (2016) worked to the utilization of plastic bags waste which was made from polyethylene polymer as material for making of non-apparel textile fibers to enhance the economic value of plastic waste. This study used plastic bags waste that was processed into filament fibers by melt spinning method[14]. Qiaoli (2019) worked to the recycling of polyethylene bags into high-strength yarns without using melt processing. Only simple cutting and yarn processing devices are needed[15]. First, HDPE grocery bags were cut into stripes through the direction of bag sealing become loop shape. Next, loops were knotted together to form a long chain. Afterward, the chain-like material is twisted to form a precursor yarn. Finally, the precursor was drawn to form a continuous yarn of a fine diameter. These fibers and yarns can then be used as constituent materials for ropes, ruggers, and textile products that are valuable to end-users.

Different with all research reference at paragraph before, this research has aims to utilize PET type plastic waste was used as raw material for making monofilament 
yarn by the melt-spinning process and to know how the effect of the winding speed on physical and mechanical properties of the yarn. Monofilament yarn is a yarn which is made from a single filament [5]. Generally, this process consists of extrusion of a molten polymer through small capillary holes (spinneret) followed by quenching with air flow while being drawn and taking up of the solidified fibers at high velocity [16][2]. Actually, melt-spinning process involves complex interactions of convective heat-transfer, polymer rheological behavior and fiber quenching process [17-21]. Monofilament yarns are widely used as textile materials, conductive yarn [22], fishing lines, toothbrush bristles, and other applications [23] .

\section{EXPERIMENTAL METHOD}

\section{Materials and Instruments}

The raw material used in making monofilament yarn was commercial PET waste from Bukalapak.com. The form of PET waste used was a little chop like a chip from plastic bottle waste (Figure 2). The material has been characterized in advance by ATR-FTIR with the

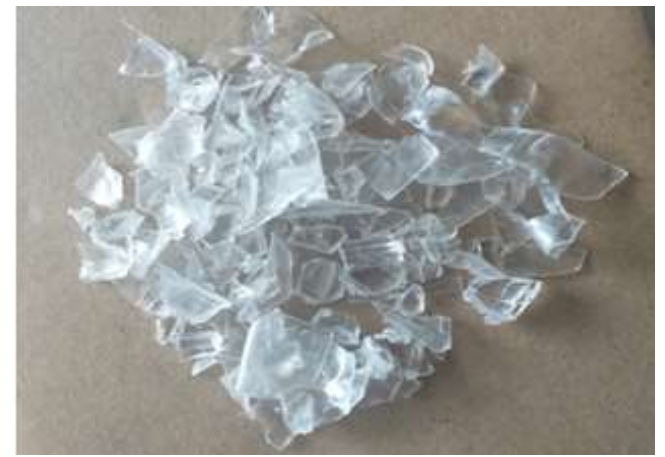

Figure 2. PET waste from plastic bottle

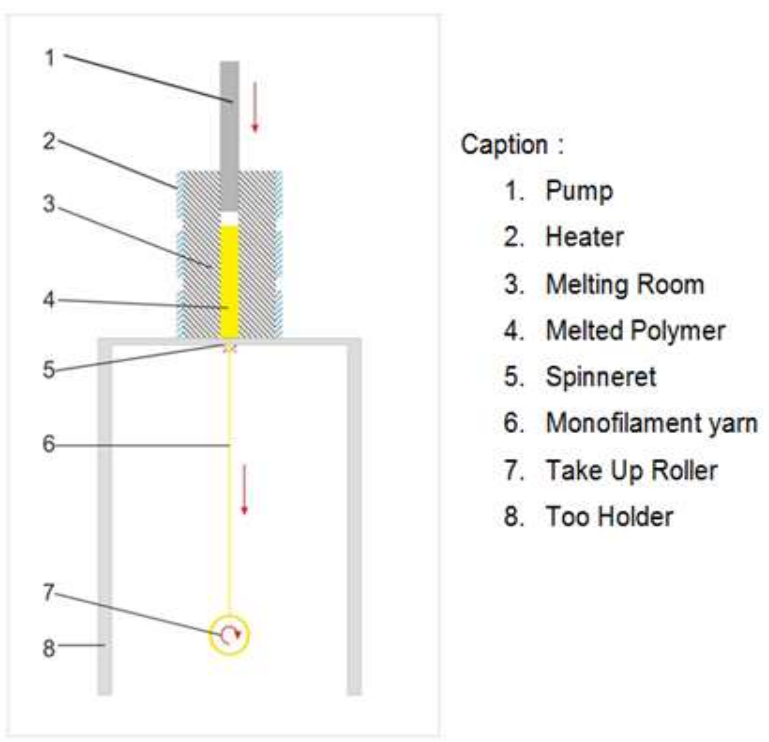

Figure 3. Melt-spinning prototype mechanism
IRAffinity-1S (Shimadzu) spectrometer belonging to the Evaluation Laboratory Politeknik STTT Bandung.

The monofilament yarn making process was carried out using a prototype melt spinning [24] at Politeknik STTT Bandung. The working mechanism of the melt-spinning prototype used in this study was different from the melt spinning in general that uses screw-type extruders as equipment to flow the molten polymer [25] but uses a pump mechanism as shown in Figure 3.

\section{Method and Procedure}

\section{Melt Spinning}

In this research, extruding PET waste into monofilament yarn was adjusted according to the character of the material. After several attempts and adjustments, the ideal conditions for melt spinning was carried out with procedure as Table 2 .

Table 2. Melt spinning process parameters

\begin{tabular}{cc}
\hline Parameter & Condition \\
\hline Extrusion Temperature & $250-260^{\circ} \mathrm{C}$ \\
Spinneret Diameter & $3 \mathrm{~mm}$ \\
Winding Distance & $47 \mathrm{~cm}$ \\
\hline
\end{tabular}

In this study, three groups of monofilament yarn produced from the melting spun of PET waste. the meltspinning process was done by variation winding speed could become three variations as Table 3 to know how the effect of winding speed on the physical and mechanical properties of the yarn. The winding speed variation were chosen based on availability speed of the melt spinning machine.

Table 3. Variaton of Winding Speed

\begin{tabular}{cc}
\hline Type Yarn & Winding Speed $(\mathrm{m} / \mathrm{min})$ \\
\hline A & 43.33 \\
B & 59.35 \\
C & 72.72 \\
\hline
\end{tabular}

\section{Physical and Mechanical Properties Test}

The yarn's physical property which has been evaluated is the fineness of the yarn. The fineness of yarn is known as a linear density of the yarn. It is also called yarn count. Yarn count is expressed by comparing the yarn mass ( $\mathrm{g}$ ) per unit of length. Denier is most commontly used top expreesed the count of continuous filament yarn of man made fiber. It show the weight of yarn in grams of 9000 meters [26]. As an example, a 40 denier yarn means that the mass of $9000 \mathrm{~m}$ of yarn is $40 \mathrm{~g}$.

Characterization of surface morphology and yarn cross-section was carried out using a Scanning Electron Microscope (SEM) brand JEOL belonging to the 
The Utilization of PET Waste as Raw Material for Producing Monofilament Yarn: The Effect of Winding Speed on the Physical and Mechanical Properties of the Yarn (Abdurrohman)

Research Unit for Clean Technology, Indonesian Institute of Science (LIPI) Bandung. Mechanical properties test of yarn was done by measured the tensile strength and elongation testing using Tensile Strength Tester brand Instron belonging to the Evaluation Laboratory Politeknik STTT Bandung with a speed of $50 \mathrm{~mm} / \mathrm{min}$ and used a weight of 50 grams. All the obtained results represent average values of ten measurements.

\section{RESULT AND DISCUSSION}

\section{Material Characterization using FTIR}

From the Transmittance graph of the FTIR test results in Figure 4, it was confirmed that the result of FTIR test was similar to bond type data in the Table 4. It can be concluded that the material used was PET although not pure PET.

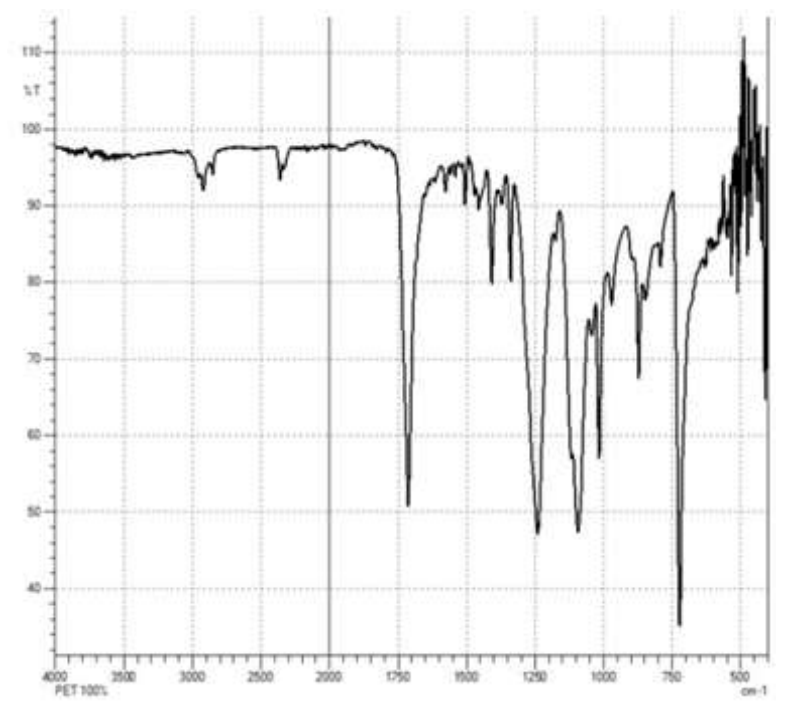

Figure 4. Transmittance graph of FTIR test results on plastic waste materials.

Table 4. The type of bond in each absorption band (cm-1) from the FTIR Spectrum Test results on a sample of 100\% PET [27].

\begin{tabular}{|c|c|}
\hline $\begin{array}{l}\text { Absorption bands } \\
\qquad\left(\mathrm{cm}^{-1}\right)\end{array}$ & Bands \\
\hline 3432 & OH group (hydroxyl) \\
\hline 3054 & Symmetrical stretch of $\mathrm{CH}$ \\
\hline 2969,2908 & C-H Symmetrical stretching \\
\hline 2350 & Axial symmetrical deformation of $\mathrm{CO}_{2}$ \\
\hline 1730 & Stretching of $\mathrm{C}=\mathrm{O}$ of carboxylatee acid group \\
\hline 1577,1504 & Vibrations aromatic skeleton with stretching $\mathrm{C}=\mathrm{C}$ \\
\hline $1453,1410,1432$ & $\begin{array}{l}\text { Stretching of the C-O group deformation of the } \\
\text { O-H group and bending and wagging vibrational } \\
\text { modes of the ethylene glycol segment }\end{array}$ \\
\hline 1240,1124 & Terephthalatee group $\left(\mathrm{OOCC}_{6} \mathrm{H}_{4}-\mathrm{COO}\right)$ \\
\hline 1096,1050 & $\begin{array}{l}\text { Methylene group and vibrations of the ester } \\
\mathrm{C}-\mathrm{O} \text { bond }\end{array}$ \\
\hline $972,872,848$ & Aromatic rings $1,2,4,5$. Tetra replaced \\
\hline 1960,795 & $\begin{array}{l}\text { Vibration of adjacent two aromatic } \mathrm{H} \text { in } \\
\text { p-substituted compounds and aromatic bands }\end{array}$ \\
\hline 712 & Interaction of polar ester group and benzene rings \\
\hline
\end{tabular}

\section{Physical and Mechanical Properties Test Result}

The effect of winding speed on the physical properties of monofilament yarn is shown in Figures 5 and 6 . In this study the variation of winding speed from $43.33 \mathrm{~m} / \mathrm{min}$ (yarn A), $59.35 \mathrm{~m} / \mathrm{min}$ (yarn B), to 72.72 (yarn C) affected the fineness and yarn diameter became finer from $(52.36 \pm 5.61)$ denier to $(30.06 \pm 4.82)$ denier (Figure 5) and yarn diameter from $(85 \pm 9.17) \mu \mathrm{m}$ to $(53 \pm 9.86) \mu \mathrm{m}$ (Figure 6).

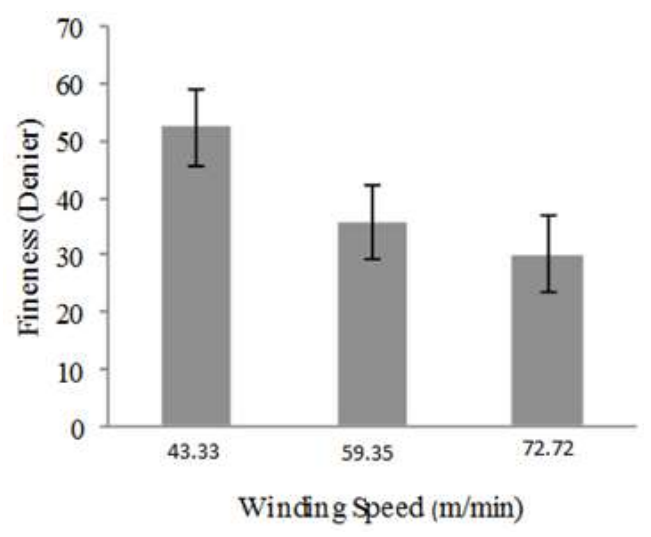

Figure 5. Fineness yarn (denier) of monofilament yarn with different winding speed $(\mathrm{m} / \mathrm{min})$.

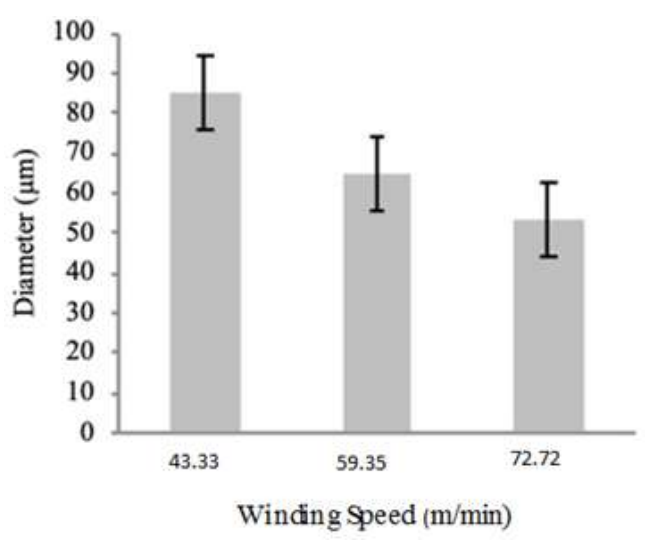

Figure 6. Yarn diameter $(\mu \mathrm{m})$ of monofilament yarn with different winding speed $(\mathrm{m} / \mathrm{min})$

This result suggested that the higher of the winding speed, the finer is the yarn finesess as well as the yarn diameter. In constant throughput speed $\left(\mathrm{V}_{1}\right)$ condition, the increasing of winding speed $\left(\mathrm{V}_{2}\right)$ will increase the drafting ratio so the strain of yarn will become longer. It will affect to increase the area depreciation of yarn and caused decreased yarn diameter after the draft $\left(D_{2}\right)$ so the fineness of yarn will become finer. The mechanism of decreasing the diameter of yarn is shown in Figure 7.

The result of the yarn mechanical properties test shown in Figure 10. The higher the increase of winding speed from $43.33 \mathrm{~m} / \mathrm{min}$ to $72.72 \mathrm{~m} / \mathrm{min}$, the higher is the tensile strength of yarn from $(34.62 \pm 5.01) \mathrm{MPa}$ to $(47.71 \pm$ 


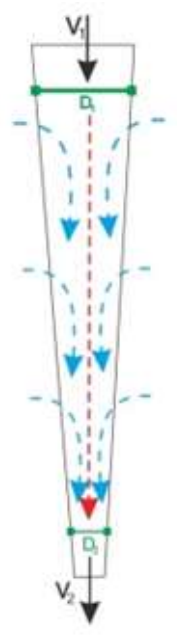

Figure 7. The mechanism of decreasing diameter of yarn.
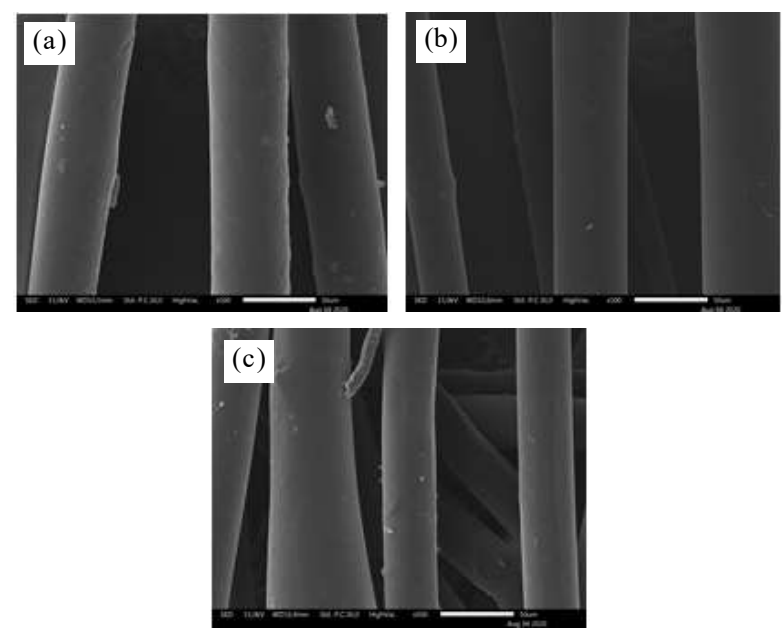

Figure 8. Surface of the monofilament yarn with different winding speed variation by SEM with a magnifi cation of $500 \mathrm{x}$ (a) $43.33 \mathrm{~m} / \mathrm{min}$, (b) $59.35 \mathrm{~m} / \mathrm{min}$, (c) $72.72 \mathrm{~m} / \mathrm{min}$.
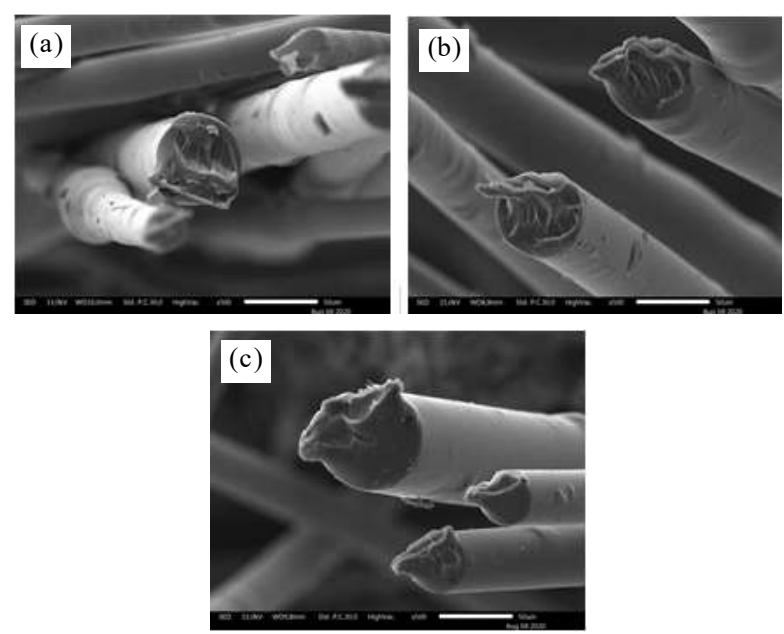

Figure 9. Cross-section of the monofilament yarn with different winding speed variation by SEM with a magnification of $500 \mathrm{x}$ (a) $43.33 \mathrm{~m} / \mathrm{min}$, (b) $59.35 \mathrm{~m} / \mathrm{min}$, (c) $72.72 \mathrm{~m} / \mathrm{min}$.
4.97) $\mathrm{MPa}$ (Figure 9a). This result suggested that the increase of winding speed increased tensile strength yarn. Tensile strength yarn was influenced by the degree of orientation. Yarn with a better orientation degree had better tensile strength[28]. The drafting process that caused by winding speed affected the orientation process of the yarn structure, if the cooling rate is slower than winding speed, the stretch of yarn will be higher so that the crystal structure of the yarn will be better oriented and amorphous phase will decrease[29].
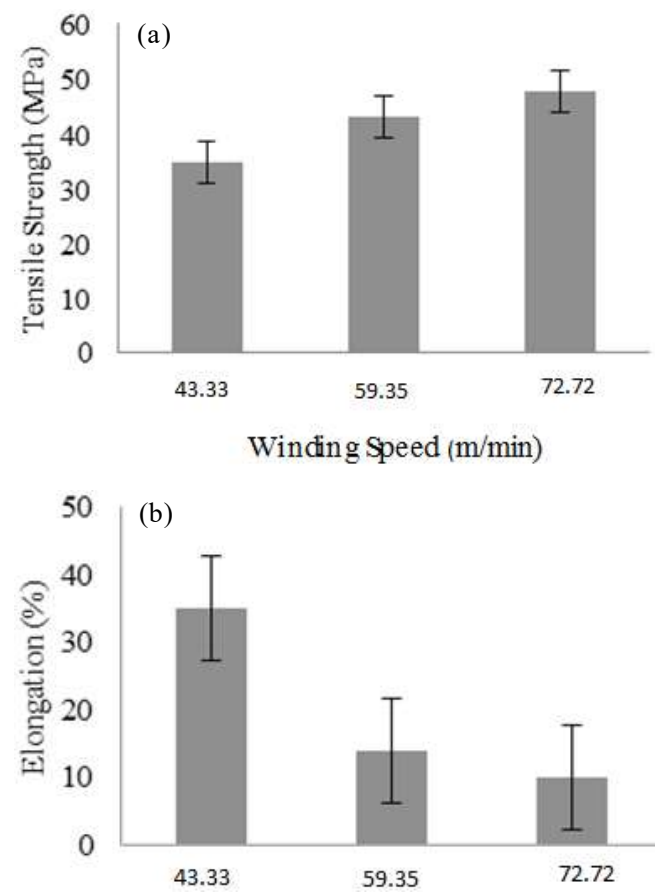

Figure 11. (a) Tensile strength and (b) Elongation at break of monofilament yarn with different winding speed.

In contrast, the elongation at break of monofilament yarn showed contrariwise. The increase of winding speed from $43.33 \mathrm{~m} / \mathrm{min}$ to $72.72 \mathrm{~m} / \mathrm{min}$ decreased elongation from $(35 \pm 9.89) \%$ to $(10 \pm 9.65) \%$ (figure 9b). It caused by increasing winding speed, orientation degree will increase and the amorphous

Table 5. Relationship between winding speed with fineness and diameter, tensile strength, and elongation of monofilament yarn.

\begin{tabular}{lccc}
\hline Sample & $\begin{array}{c}\text { Winding Speed } \\
(\mathrm{m} / \mathrm{min})\end{array}$ & $\begin{array}{c}\text { Fineness } \\
(\text { denier })\end{array}$ & $\begin{array}{c}\text { Diameter } \\
(\mu \mathrm{m})\end{array}$ \\
\hline Yarn A & 43.33 & $(52.36 \pm 5.61)$ & $(85 \pm 9.17)$ \\
Yarn B & 59.35 & $(35.74 \pm 5.40)$ & $(65 \pm 9.23)$ \\
Yarn C & 72.72 & $(30.06 \pm 4.82)$ & $(53 \pm 9.86)$ \\
\hline
\end{tabular}

Table 6. Relationship between winding speed with tensile strength, and elongation of monofilament yarn.

\begin{tabular}{cccc}
\hline Sample & $\begin{array}{c}\text { Winding Speed } \\
(\mathrm{m} / \mathrm{min})\end{array}$ & $\begin{array}{c}\text { Tensile Strength } \\
(\mathrm{MPa})\end{array}$ & $\begin{array}{c}\text { Elongation } \\
\text { at Break }(\%)\end{array}$ \\
\hline Yarn A & 43.33 & $(34.62 \pm 5.01)$ & $(35 \pm 9.89)$ \\
Yarn B & 59.35 & $(43.10 \pm 4.88)$ & $(14 \pm 9.78)$ \\
Yarn C & 72.72 & $(47.71 \pm 4.97)$ & $(10 \pm 9.65)$ \\
\hline
\end{tabular}


The Utilization of PET Waste as Raw Material for Producing Monofilament Yarn: The Effect of Winding Speed on the Physical and Mechanical Properties of the Yarn (Abdurrohman)

phase will decrease[28]. If the amorphous phase decreases, it will affect space for a stretch at yarn structure to become less.

\section{CONCLUSION}

In this research, monofilament yarn was produced from PET waste via the melt-spinning process. The effect of winding speed $(43.33 \mathrm{~m} / \mathrm{min}, 59.35 \mathrm{~m} / \mathrm{min}$, and 72.72 $\mathrm{m} / \mathrm{min}$ ) on the physical and mechanical properties of the yarn produced were investigated. The test results showed that the increasing winding speed improved the fineness of the yarn and reduce the diameter of yarn from $(52.36 \pm 5.61)$ denier to $(30.06 \pm 4.82)$ denier and from $(85 \pm 9.89) \mathrm{mm}$ to $(53 \pm 9.65) \mu \mathrm{m}$ as well as improved the tensile strength of yarn and reduce elongation at break of yarn from $(34.62 \pm 5.01) \mathrm{MPa}$ to $(47.71 \pm 4.97) \mathrm{MPa}$ and from $35 \%$ to $10 \%$.

\section{ACKNOWLEDGMENT}

The authors would like to appreciate The Department of Textile Engineering, Politeknik STTT Bandung and Research Unit for Clean technology, Indonesian Institute of Science (LIPI) for their contribution and support.

\section{REFERENCES}

[1] H. P. Putra dan Y. Yuriandala, "Studi Pemanfaatan Sampah Plastik Menjadi Produk dan Jasa Kreatif," J. Sains \&Teknologi Lingkung., vol. 2, no. 1, hal. 21-31, 2010, doi: 10.20885/jstl.vol2.iss1.art3.

[2] A. D. A. Jatmiko Wahyudi, Hermain Teguh Prayitno, "Pemanfaatan Limbah Plastik Sebagai Bahan Baku Pembuatan Bahan Bakar Alternatif," J. Litbang, vol. XIV, no. 1, hal. 58-67, 2018.

[3] M. Syamsiro $d k k$., "Fuel oil production from municipal plastic wastes in sequential pyrolysis and catalytic reforming reactors," Energy Procedia, vol.47, hal. 180-188, 2014, doi: 10.1016/ j.egypro.2014.01.212.

[4] N. Karuniastuti, "Bahaya Plastik terhadap Kesehatan dan Lingkungan," Swara Patra Maj. Pusdiklat Migas, vol. 3, no. 1, hal. 6-14, 2013.

[5] F. Rian, "PRARANCANGAN PABRIK BENANG POY 165 / 96 SDC DENGAN KAPASITAS 8.000 TON / TAHUN," Tugas Akhir, Univ. Islam Indones., 2018.

[6] S. Chowdhury, A. T. Maniar, dan O. Suganya, "Polyethylene Terephthalate ( PET ) Waste as Building Solution," Int. J. Chem. Environ. Biol. Sci., vol. 1, no. 2, hal. 2320-4087, 2013.

[7] U. B. Surono, "Berbagai Metode Konversi Sampah Plastik,” J. Tek., vol. 3, no. 1, hal. 32-40, 2013.

[8] S. Das dan S. Paney, "Pyrolysis and Catalytic Cracking of Municipal Plastic Waste for Recovery of Gasoline Range Hydrocarbons Pyrolysis and Catalytic Cracking of Municipal Plastic Waste for Recovery of Gasoline Range Hydrocarbons," Thesis Natl. Inst. Technol. Rourkela, hal. 10-55, 2007.

[9] N. K. Madi, "Thermal and mechanical properties of injection molded recycled high density polyethylene blends with virgin isotactic polypropylene," Mater. Des., vol. 46, hal. 435-441, 2013, doi: 10.1016/j.matdes.2012.10.004.

[10] E. Devaux, Understanding the behaviour of synthetic polymer fibres during spinning. Woodhead Publishing Limited, 2014.

[11] B. Hu, S. Serranti, N. Fraunholcz, F. Di Maio, dan G. Bonifazi, "Recycling-oriented characterization of polyolefin packaging waste," Waste Manag., vol. 33, no. 3, hal. 574-584, 2013, doi: 10.1016/ j.wasman.2012.11.018.

[12] Dulmalik, A. Chafidz, R. Fernandi, dan Ardianto, "Partially Oriented Yarn (POY) produced from semidull via melting spun using an extruder: Effect of die extruder temperature on elongation of the POY," J. Phys. Conf. Ser, vol. 1295, no. 1, 2019, doi: 10.1088/1742-6596/1295/1/012010.

[13] E. M. Aizenshtein, "BOTTLE WASTES “ TO TEXTILE YARNS,” vol. 47, no. 5, hal. 3-7, 2020, doi: 10.1007/s10692-016-9691-8.

[14] Noerati, A. S. Soekoco, M. Komalasari, Kurniawan, dan A. Hananto, "Pembuatan Serat Tekstil Bukan Sandang dari Limbah kantong plastik polietilen," Semin. Utomo Pemanfaat. Sumber Daya Alam untuk Meningkat. Daya Saing Ind. Proses Nas. . ITENAS, hal. kimia 1-3, 2016.

[15] Q. Xu, H. Yi, X. Gao, J. Shi, dan D. Yao, "Recycling of Polyethylene Bags into High-Strength Yarns Without Using Melt Processing," Polym. Eng. Sci., vol. 60 , no. 2 , hal. 281-287, 2020, doi: 10.1002/ pen.25281.

[16] F. A. Reifler, R. Hufenus, M. Krehel, E. Zgraggen, R. M. Rossi, dan L. J. Scherer, "Polymer optical fibers for textile applications - Bicomponent melt spinning from cyclic olefin polymer and structural characteristics revealed by wide angle X-ray diffraction," Polymer (Guildf)., vol. 55, no. 22, hal. 5695-5707, 2014, doi: 10.1016/ j.polymer.2014.08.071.

[17] S. M. Ghoreishian dkk., "Optimization of meltspinning parameters of poly(ethylene terephthalate) partially oriented multi-filament yarn in an industrial scale: Central composite design approach," Fibers Polym., vol. 18, no. 7, hal. 1280 1287, 2017, doi: 10.1007/s12221-017-1119-4.

[18] M. Norouzi, Y. Zare, dan P. Kiany, "Nanoparticles as effective flame retardants for natural and synthetic textile polymers: Application, mechanism, and optimization," Polym. Rev., vol. 55, no. 3, hal. 531-560, 2015, doi: 10.1080/15583724.2014.980427. 
[19] M. Norouzi, L. M.-A. J. of Chemistry, dan undefined 2010, "Photocatalytic Effects of Nanoparticles of $\mathrm{TiO}^{\wedge}$ sub $2^{\wedge}$ in Order to Design Self-Cleaning Textiles," Asian J. Chem.

[20] M. Norouzi, B. Nazari, dan D. W. Miller, "Injectable hydrogel-based drug delivery systems for local cancer therapy," Drug Discov. Today, vol. 21, no. 11, hal. 1835-1849, 2016, doi: 10.1016/ j.drudis.2016.07.006.

[21] O. Babaarslan dan S. Ö. Hacioçullari, "Effect of fibre cross-sectional shape on the properties of POY continuous filaments yarns," Fibers Polym., vol. 14, no. 1, hal. 146-151, 2013, doi: 10.1007/ s12221-013-0146-Z.

[22] A. Ferreira, F. Ferreira, dan M. C. Paiva, "Textile Sensor Applications with Composite Monofilaments of Polymer / Carbon Nanotubes," Adv. Sci. Technol., vol. 80, hal. 65-70, 2012, doi: 10.4028/www.scientific.net/ast.80.65.

[23] J. Hagewood, Technologies for the manufacture of synthetic polymer fibers. Woodhead Publishing Limited, 2014.

[24] A. S. Soekoco, D. Mustafa, Rosmawat, dan Jane, "Recycled fiber from straw waste: Effect of takeup speed and spinneret diameter to linear density and tenacity," MATEC Web Conf., vol. 154, hal. 2-5, 2018, doi: 10.1051/matecconf/ 201815401119.

[25] A. Rawal dan S. Mukhopadhyay, Melt spinning of synthetic polymeric filaments, no. 1976. Woodhead Publishing Limited, 2014.

[26] K. Hari, P, "Types and properties of fibres and yarns used in weaving 1," in Woven Textile, Woodhead Publishing Limited, 2012, hal. 3-34.

[27] A. P. Dos Santos Pereira, M. H. P. Da Silva, É. P. Lima, A. Dos Santos Paula, dan F. J. Tommasini, "Processing and characterization of PET composites reinforced with geopolymer concrete waste," Mater. Res., vol. 20, hal. 411-420, 2017, doi: 10.1590/1980-5373-MR-2017-0734.

[28] S. . Zhurkov, I. . Novak, B. Y. Levin, A. . Savitskii, dan V. . Vettegren, "Relation Between Polymer Strength And Molf Ular Orientation," no. 7, hal. 1203-1207, 1965.

[29] A. J. Uddin, Y. Ohkoshi, Y. Gotoh, M. Nagura, R. Endo, dan T. Hara, "Effects of take-up speed of melt spinning on the structure and mechanical properties of maximally laser drawn PA9-T fibers," Int. Polym. Process., vol. 21, no. 3, hal. 263-271, 2006, doi: 10.3139/217.0090. 